Niepełnosprawność. Dyskursy pedagogiki specjalnej

Nr 32/2018

Disability. Discourses of special education

No. 32/2018

Agnieszka Woynarowska

Uniwersytet Gdański

\title{
Europejskie studia nad niepełnosprawnością. Analiza wątków badawczych i obszarów zainteresowań ALTER - European Society for Disability Research
}

Artykuł prezentuje obszary badań europejskich studiów nad niepełnosprawnością. Autorka analizuje problematykę badawczą i wątki tematyczne podejmowane przez badaczy zrzeszonych wokół Alter - European Society for Disability Research. Analizie poddaje 200 wystąpień zaprezentowanych na następujących konferencjach: $4^{\text {th }}$ annual conference of Alter: Questioning contemporary societies through the lens of disability, Paris 2015; $5^{\text {th }}$ annual conference of Alter: Inclusion, Participation and Human Rights in Disability Research comparisons and exchanges, Stockholm 2016; $6^{\text {th }}$ annual conference of Alter: Disability, Recognition and "Community living". Diversity of practises and plurality of values, Lausanne 2017; 7th annual conference of Alter: Transformer les pratiques et les connaissances au prisme du handicap : expériences, transmissions, formations, organisations, Lille 2018.

Słowa klucze: europejskie studia nad niepełnosprawnością, nurty i obszary badawcze, Alter European Society for Disability Research

\section{European Disability Studies. The Analysis of research trends and research issues of ALTER - European Society for Disability Research}

The article presents the research trends of European Disability Studies. The author analyzes the research topics and issues undertaken by researchers associated with the Alter - European Society for Disability Research. The analysis covers 200 conference papers which have been presented at the following conferences: $4^{\text {th }}$ annual conference of Alter: Questioning contemporary societies through the lens of disability, Paris 2015; $5^{\text {th }}$ annual conference of Alter: Inclusion, Participation and Human Rights in Disability Research comparisons and exchanges, Stockholm 2016; 6th annual conference of Alter: Disability, Recognition and "Community living". Diversity of practises and plurality of values, Lausanne 2017; $7^{\text {th }}$ annual conference of Alter: Transformer les pratiques et les connaissances au prisme du handicap : expériences, transmissions, formations, organisations, Lille 2018.

Keywords: European Disability Studies, research trends and topics, Alter - European Society for Disability Research 


\section{Wprowadzenie}

Niepełnosprawność jest nieodłącznym elementem ludzkiej egzystencji. Bardzo różnorodnie doświadczana, postrzegana i przeżywana przestała być tylko elementem indywidualnego doświadczenia czy osobistej tragedii, a stała się zjawiskiem nierozłącznie wpisującym w rzeczywistość społeczną i daną kulturę. Temat niepełnosprawności jest badany i ukazywany $\mathrm{w}$ wielu płaszczyznach czy obszarach przez badaczy owego zjawiska na całym świecie. W niniejszym tekście chciałabym przedstawić wątki, nurty badawcze oraz płaszczyzny interpretacji zjawiska niepełnosprawności podejmowane przez badaczy europejskich zrzeszonych wokół ALTER - European Society for Disability Research. Alter, założone w 2011 r., ma na celu promowanie badań w dziedzinie nauk humanistycznych i społecznych dotyczących niepełnosprawności, podkreślając wielość naukowych podejść i wiedzy. Alter jest społecznością naukową dla wszystkich osób zainteresowanych niepełnosprawnością i problemami, które porusza, bez żadnych zastrzeżeń, co do kierunków badań.

Alter corocznie, cyklicznie organizuje konferencje naukowe w różnych europejskich ośrodkach akademickich. Ich celem jest zaoferowanie europejskiego i międzynarodowego multidyscyplinarnego spojrzenia na badania nad niepełnosprawnością w całym jej spektrum. Uznanie niepełnosprawności za kategorię analizy w perspektywie politycznej, historycznej czy subiektywnego doświadczenia rzuca światło na sposoby organizacji współczesnych społeczeństw. Konferencje Alter są miejscem prezentowania badań, sposobów rozumienia i interpretowania niepełnosprawności lokowanych głównie w obszarze Disability Studies i Critical Disability Studies. Aby odpowiedzieć na pytanie, jakie wątki i nurty badawcze zjawiska niepełnosprawności podejmowane są przez naukowców w Europie i na świecie poddałam analizie 200 wystąpień prezentowanych na czterech corocznych konferencjach ALTER ${ }^{1}$. Dokonując analizy treści prezentacji wyszczególniłam dziewięć obszarów tematycznych, w których najczęściej toczą się badania. Są to: polityka wobec niepełnosprawności/prawa osób niepełnosprawnych; ruchy społeczne osób niepełnosprawnych/niepełnosprawni aktywiści; społeczno-kulturowe konstrukcje niepełnosprawności i w tym: repre-

\footnotetext{
1 Analizie poddano treści wystąpień ustnych i zapisanych w abstraktach z następujących konferencji: $4^{\text {th }}$ annual conference of Alter: Questioning contemporary societies through the lens of disability, Paris 2015; $5^{\text {th }}$ annual conference of Alter: Inclusion, Participation and Human Rights in Disability Research comparisons and exchanges, Stokholm 2016; $6^{\text {th }}$ annual conference of Alter: Disability, Recognition and "Community living". Diversity of practises and plurality of values, Lausanne 2017; $7_{\text {th }}$ annual conference of Alter: Transformer les pratiques et les connaissances au prisme du handicap : expériences, transmissions, formations, organisations.,Lille 2018. Od 2015 r. jestem członkiem ALTER, razem z D. Krzemińską, I. Lindyberg, J. Rzeźnicką-Krupą; uczestniczyłam czynnie w trzech konferencjach.
} 
zentacje niepełnosprawności w mediach, literaturze i dyskursie publicznym, relacje społeczne - społeczne rozpoznanie/rozumienie niepełnosprawności. Kolejne obszary odnoszą się do modeli edukacji, polityki zatrudnienia osób niepełnosprawnych, jak i modeli wsparcia zatrudnienia, ciała, płci i seksualności, nowych technologii - dostępności, środowiska, architektury oraz niepełnosprawności i sztuki.

Zanim przejdę do omówienia wybranych obszarów zatrzymam się przy nurcie Disability Studies. Jak objaśniałam powyżej badania prowadzone przez badaczy skupionych wokół ALTER lokują się w płaszczyźnie Disability Studies, Critical Disability Studies, Cultural Disability Studies. Disability Studies to dyscyplina naukowa, która analizuje znaczenia, naturę i konsekwencje niepełnosprawności postrzeganej jako zjawisko społecznie konstruowane, czy wytwór kulturowych praktyk i ich interpretacji. Disability Studies swoimi eksploracjami obejmuje badania $\mathrm{m}$.in. historii niepełnosprawności, teorii, prawodawstwa, polityki, etyki, sztuki, literatury, mediów czy ruchów społecznych aktywistów z niepełnosprawnościami oraz wpisuje się w sposób myślenia o niepełnosprawności zawarty w modelu kulturowym. W 1994 r. Tom Shakespeare wezwał do zwrócenia większej uwagi na kulturowe reprezentacje osób niepełnosprawnych. Zainspirowany debatami feministycznymi omówił różne podejścia teoretyczne i zasugerował, że "osoby niepełnosprawne są uprzedmiotawiane przez reprezentacje kulturowe". Przez reprezentacje kulturowe rozumiał teatr, literaturę, obrazy, filmy i media [Shakespeare 1994: 283-299].

W 2006 r. S. Snyder i D. Mitchell wprowadzili koncepcję „kulturowego modelu niepełnosprawności”. W ich założeniach "model kulturowy zapewnia pełniejszą koncepcję niż model społeczny, w którym «niepełnosprawność» oznacza wyłącznie dyskryminujące spotkania. Sformułowanie modelu kulturowego pozwala nam teoretyzować polityczny akt zmiany, który określa niepełnosprawność jako miejsce oporu i źródło kultury uprzednio stłumionej" [Snyder, Mitchell 2006: 10]. Ponadto w perspektywie Snyder i Mitchell podejście oparte na modelu kulturowym ma tendencję do rozpoznawania tożsamości i ciała jako konstruowanych [tamże, s. 10]. A. Waldschmit nawiązując do anglosaskiej koncepcji kulturowego modelu niepełnosprawności zwraca uwagę, że w perspektywie tego modelu niepełnosprawność nie jest widziana przez pryzmat pojedynczego losu, jak $\mathrm{w}$ indywidualistyczno-redukcjonistycznym modelu niepełnosprawności. Nie jest też zwykłym efektem dyskryminacji i wykluczenia, jak w modelu społecznym. Przeciwnie, model kulturowy kwestionuje drugą stronę medalu, powszechnie niezagrożoną "normalność” i bada, w jaki sposób praktyki (de-)normalizacji prowadzą do kategorii społecznej, którą nazwaliśmy „niepełnosprawnością" [Waldschmit 2017: 22]. Jak dalej objaśnia ta autorka, kulturowy model niepełnosprawności nie powinien traktować niepełnosprawności jako jednoznacznej kategorii 
klasyfikacji patologicznej, która automatycznie, w formie związku przyczynowego, powoduje dyskryminację społeczną. Przeciwnie, model ten uwzględnia niepełnosprawność i normalność jako efekty generowane przez wiedzę akademicką, środki masowego przekazu i codzienne dyskursy [tamże, s. 24]. W każdej kulturze w danym momencie klasyfikacje te zależą od struktur władzy i sytuacji historycznej, są zależne i zdeterminowane przez hegemoniczne dyskursy. W skrócie, model kulturowy uznaje niepełnosprawność nie za daną jednostkę czy fakt, ale opisuje ją jako dyskurs lub proces, doświadczenie, sytuację lub wydarzenie. Zarówno niepełnosprawność (disability), jak i sprawność (ability) odnoszą się do dominujących symbolicznych porządków i instytucjonalnych praktyk wytwarzania normalności i dewiacji, znanego i odmiennego. Zakładając konstruktywistyczny i dyskursywny charakter niepełnosprawności, można wziąć pod uwagę historyczną i kulturową perspektywę kreowania procesów włączenia i wykluczenia, stygmatyzacji jak również społeczno-kulturowe wzorce doświadczenia i tożsamości, tworzenia znaczeń i praktyk społecznych, władzy i oporu [Waldschmit 2017: 23].

Ponadto $\mathrm{w}$ analizowanych europejskich badaniach pojawiają się także odniesienia do różnorodnych teorii interpretujących niepełnosprawność i jej bycie w świecie. Obecna jest teoria transhumanizmu czy bardzo ostatnio eksponowana przez aktywistów/artystów/performerów z niepełnosprawnościami: Crip theory. W swoim wystąpieniu D. Doat pyta: Which teory of Disability does transhumanism presuppose? Badacz m.in. zadaje sobie pytanie, jak osoby niepełnosprawne są postrzegane w polu transhumanizmu, a odpowiadając na nie ukazuje, że osoby niepełnosprawne $w$ transhumanistycznej kulturze widziane są jako niekompletne i doświadczające frustracji, a ów stan może być zmieniony przez nowe technologie: protezy, implanty i inne pomocnicze technologie, podnoszące ich jakość życia. W poglądach autora wystąpienia owo założenie jest wątpliwe podobnie jak i transumanistyczny pogląd, że każdy człowiek jest z konieczności niepełnosprawny w odniesieniu do osób transhumanistycznych [Doat 2016].

Crip theory to teoria opisana i wyjaśniona przez Roberta McRuer'a. Zanim jednak weszła do terminologii naukowej, słowo crip używane było przez aktywistów i artystów z niepełnosprawnością $\mathrm{w}$ celu budowania alternatywnej tożsamości. Jak wyjaśnia R. McRuer, angielskie słowo crip, pochodzące od słowa kaleka, podobnie jak słowo queer (pedał/odmieniec), ma długą i zawiłą historię. Od mniej więcej dwudziestu lat crip funkcjonuje w obrębie akademickich badań nad niepełnosprawnością, jako nazwa radykalnej alternatywy dla asymilacjonistycznego czy też reformistycznego podejścia do niepełnosprawności. Zatem crip odgrywa tu taką samą rolę jak queer $\mathrm{w}$ stosunku do studiów lesbijskich i gejowskich [McRuer 2016]. Jak dalej zauważa, słowo crip zawsze będzie się kojarzyć z historią napiętnowania i pogardy. Jednak na przekór temu co bolesne, słowo crip zostało 
odzyskane. Sam termin „niepełnosprawność” również został odzyskany. O ile w przeszłości słowo to automatycznie kojarzyło się z utratą, brakiem czy wykluczeniem, o tyle dziś może oznaczać tożsamość czy przynależność do kultury niepełnosprawności [McRuer 2016]. Nawiązując do Snyder i Mitchel, twierdzi, że źródłosłów crip związany z kalectwem stał się wyznacznikiem nowego wzorca niepełnosprawności ujawnionej i dumnej [Snyder, Mitchel 2006, za: McRuer 2016].

Wzorzec ten, jak dalej pisze, jest przeciwieństwem zarówno wzorca medycznego, ograniczającego niepełnosprawność do patologii, diagnozy i leczenia/ eliminacji, jak i dobrze znanego wzorca społecznego, który sugeruje, że „niepełnosprawność" tkwi nie w ciałach tylko w nieprzyjaznym im otoczeniu, wymagającym odpowiednim udogodnień. Ekstrawagancka i wyzywająca postawa "kalek" jest związana z bardziej twórczymi kulturowo i radykalnymi politycznie wzorcami niepełnosprawności niż reformistyczny model społeczny [McRuer 2016]. Kontekst Crip theory pojawia się u wielu tekstach badaczy ALTER. Jeden $\mathrm{z}$ nich: Cripping the future: making disability count, F. Ginsburg, R. Rapp, traktuje o sposobach rozpoznawania, nazywania i umiejscowienia niepełnosprawności w kulturze Ameryki Północnej [Ginsburg, Rapp 2015].

\section{Polityka wobec niepełnosprawności/ prawa osób niepełnosprawnych}

Pierwszy z wyróżnionych przeze mnie nurtów badawczych odnosi się do analiz polityk różnych krajów względem swoich niepełnosprawnych obywateli oraz ukazania, co konkretnego dla osób z niepełnosprawnością, wynika z określonych politycznych działań. Badacze analizują w jaki sposób odnoszą się do rzeczywistości i są jak są urealnione zapisane w poszczególnych aktach prawnych, danych państw, prawa osób niepełnosprawnych. Prawa do wspólnego życia $\mathrm{w}$ jednym nurcie społecznym, czy prawa do inkluzji. O takich działaniach i ich skutkach traktują m.in. analizy S. Larsson: People with support from the Swedish Disability Act-included or in charge?; J. Wenckebach: Evaluating the German Federal Law of Equal Treatment of Disabled Persons methods and results; J.E. Andersson: Norwegian and Swedish disability policies in action; R. Lindqvist: Disability policies in Japan and Sweden; J. Tossebro: Scandinavian Disability Policy - from deinstitutionalization to anti-discrimination?; F. Armstrong: Disability, education and participation: a critical analysis of recent policy developments in England. Niezwykle interesujące wydają się rozważania T. Mladenov'a: Questioning productivism through the lens of disability: reflections on state socialist and postsocialist disability policy. W swoim wystąpieniu Mladenov przeanalizował bowiem politykę państw socjalistycznych i ich rozwój 
po roku 1989 w celu wyjaśnienia współczesnych form unieważnień doświadczanych przez osoby niepełnosprawne w postsocjalistycznym regionie Europy Środkowo-Wschodniej. Dokładniej, jego analiza bada stan socjalistyczny i posocjalistyczny produktywizm, podkreślając jego negatywny wpływ na życie i tożsamość osób niepełnosprawnych oraz strategie przeciwstawiania się produktywizmowi i unieważnienia osób niepełnosprawnych wywołane przez produktywistyczne społeczeństwo [Mladenov 2015].

Polityka społeczna poszczególnych europejskich państw wyznaczona jest przez koncepcję dostępności i to przez jej pryzmat toczą się kolejne wątki tematyczne tego obszaru badań. $\mathrm{W}$ artykułach przedstawia się wyniki badań dotyczących wdrażania idei dostępności czy uniwersalnego projektowania w europejskich krajach. Jak zauważają, Andersson, Balke, Skehan od połowy lat sześćdziesiątych koncepcja dostępności przekształciła się w kluczowe pojęcie, dzięki któremu współczesne społeczeństwo opiekuńcze będzie dostępne dla dużych grup ludzi, niezależnie od ich potencjału poznawczego i funkcjonalnego. Na początku koncepcja dotyczyła przede wszystkim wymagań fizycznych dla środowiska. W ramach ewolucji koncepcji w Szwecji dostępność osiągnęła zarówno drugorzędne, jak i trzeciorzędne uzupełniające się znaczenia, które odnoszą się do strategii likwidowania przestarzałych postaw dotyczących osób niepełnosprawnych oraz do zapewnienia, że artefakty i media są użyteczne dla użytkowników o zróżnicowanym zakresie umiejętności, ograniczeń i umiejętności. W 2006 r. Prawa do Konwencji ONZ dla osób niepełnosprawnych (CRPD) wiązały się z uniwersalnym myśleniem projektowym (UD) (Andersson, Balke, Skehan: Dissecting strategies for creating inclusive societies in twelve western countries, going beyond accessibility concepts and achieving universal usability, 2016).

Podejmowane badania odnoszą się zarówno do działań państw na rzecz niepełnosprawnych obywateli, jak i do praw osób niepełnosprawnych zawartych w Konwencji Praw Osób Niepełnosprawnych ONZ, która została stworzona w 2006 r. i wkrótce ratyfikowana przez większość światowych państw. Owe zapisy w Konwencji wyznaczają cele i trendy ogólnoeuropejskiej strategii na rzecz niepełnosprawności, ale także cele i zadania polityki społecznej poszczególnych krajów. Wiele badawczych wątków traktuje o realizacji postanowień Konwencji, ale także ukazuje obszary wykluczeni, braków i trudności, z którymi borykają się opisywane społeczeństwa. Jak zauważają E. Lindqvist i M. Lagercrantz [2016] w Monitoring UNCRPD in a national perspective, Konwencja Narodów Zjednoczonych o prawach osób niepełnosprawnych (CRPD) została przyjęta z dużą energią i świętowaniem. Tym ważnym traktatem o prawach człowieka dla osób niepełnosprawnych, który wszedł w życie, po raz pierwszy wkroczyliśmy w nową erę, w której należy skoncentrować się na wdrażaniu i monitorowaniu zobowiązań państw. To znaczy wyewoluowaliśmy od „porozmawiać o prawach” 
do „działań w sprawie praw”. Projekty badawcze ukazują zderzenia rzeczywistości z postulatami, ale również osadzają się w historyczno-politycznych uwarunkowaniach zmian. O takich zderzeniach traktują wystąpienia mi.in.: A. Waldschmidt: Towards cross-national convergence of disability politics? A comparative study on the involvement of disability organisations in UN CRPD implementation processes in European countries; J.E. Andersson: Nordic operationalisation of rights for people with disabilities: accessibility, inclusion, and the UNCRPD put in action in Norway and Sweden; B. Byrne: Rights-Holders under the UNCRPD: Challenging De?nitions of Disability in Human Rights. Jak pisze A. Waldschmidt, analizując zmiany w niemieckiej polityce względem niepełnosprawności, jeśli chodzi o politykę dotyczącą niepełnosprawności w zachodnich demokracjach, wydaje się, że zachodzą oczywiste zmiany. Główną przyczyną tej zmiany jest Konwencja Narodów Zjednoczonych o prawach osób niepełnosprawnych (UN CRPD). Jednocześnie jednak wdrażanie tego międzynarodowego systemu dotyczącego niepełnosprawności odbywa się na różnych płaszczyznach $\mathrm{w}$ różnych krajach, w zależności od krajowych tradycji $\mathrm{i}$ trajektorii. $\mathrm{W}$ ciągu ostatnich 15 lat nastąpiły zmiany w niemieckiej polityce i zmiany te ulegają przyspieszeniu w wyniku ratyfikacji Konwencji Narodów Zjednoczonych o prawach osób niepełnosprawnych. Niemieckie państwo opiekuńcze ma długą historię traktowania osób niepełnosprawnych bardziej jako beneficjentów pomocy społecznej niż jako obywateli o równych prawach, niemiecka polityka wobec osób niepełnosprawnych koncentruje się na integracji na rynku pracy, ale programy społeczne nie są bardzo skuteczne [A. Waldschmit: Changing Disability Policies in the Age of the UN CRPD: the Case of Germany, 2017].

\section{Ruchy społeczne osób niepełnosprawnych/ niepełnosprawni aktywiści}

Kolejny obszar badawczych eksploracji lokuje się w polu aktywizmu osób niepełnosprawnych, w polu analiz działalności ruchów społecznych środowisk osób niepełnosprawnych. Ruch społeczny według P. Sztompki, to forma zbiorowego spontanicznego działania, pewnych kategorii zbiorowości, zmierzającego do określonego celu i często do wywołania zmiany społecznej. Ruch społeczny może przyczyniać się do zmiany społecznej lub być przez nią wywołany, może zmierzać do wprowadzenia zmian lub do ich hamowania. Ruch społeczny może dążyć do wprowadzenia zmian szybko, za jednym zamachem, bądź działać na rzecz stopniowego, powolnego ich wprowadzenia. Ruchy społeczne nie tworzą skomplikowanych struktur organizacyjnych, jednakże w sytuacji, gdy mają możliwość wpływu na władzę i mogą nie tylko postulatywnie głosić potrzebę zmiany, lecz 
także zmianę tę wprowadzać, wówczas następuje ich instytucjonalizacja, przy czym same przekształcają się w organizacje [Sztompka 2005]. Na całym świecie, $\mathrm{w}$ imię disability justice, działają aktywiści z niepełnosprawnością, utożsamiający się z ruchem crip. Celem tych działań jest szeroko rozumiana zmiana. Jak zauważa R. McRuer, dla radykalnie myślących osób - crip jest kluczowym słowem, które obecnie wiąże się z tym, co wielu nazywa disability justice - „sprawiedliwością dla niepełnosprawnych". Ta wizja sprawiedliwości wykracza poza strategie oparte na domaganiu się praw i na przynależności państwowej. Taka wizja sprawiedliwości staje się podstawą antyneoliberalnych koalicji na rzecz globalnej wyobraźni kripowej, dzięki której będzie możliwe wypracowanie nowych sposobów przeciwstawiania się opresji i generowania nowych form współżycia [McRuer 2016]. Ponadto $\mathrm{w}$ procesie formułowania polityki dla osób niepełnosprawnych większy nacisk kładzie się na udział samych niepełnosprawnych w kraju i na świecie. Aktywne ruchy na rzecz praw osób niepełnosprawnych pojawiają się $\mathrm{w}$ wielu krajach. Badacze prezentujący swoje analizy na konferencjach Alter ukazują walkę aktywistów z niepełnosprawnościami o „sprawiedliwość dla niepełnosprawnych".

M. Arenas-Conejo w wystąpieniu zatytułowanym: The committees of functional diversity in the 15M movement: reformulating disability activism in Spain, prezentuje działalność aktywizmu osób niepełnosprawnych w Hiszpanii. Popularnie znany jako ruch 15M wybuchł w Hiszpanii w 2011 r. Zaczęło się od protestów przeciwko wprowadzonym przez rząd środkom oszczędnościowym, które ostatecznie przekształciły się w wielką sieć okupowanych placów publicznych w całym kraju, a nawet za granicą [Arenas-Conejo 2015]. Inne wystąpienia traktujące o historii, współczesności i walce ruchów społecznych to m.in. historie Egiptu (M. Attia: Egyptian Disability Movement: Are Voices Heard and Policies Impacted?), Norwegii, Szwecji (R. Lindqvist: Active citizenship for persons with psychosocial disabilities in Sweden: a life-course perspective), Austrii, Niemiec, Szwajcarii (L. Pfahl, Claiming Equality: Human and Social Rights in Europe: Formational Interventions of the Disability Movement in Austria, Germany and Switzerland in the 20th Century), Polski (A. Woynarowska, J. Rzeźnicka-Krupa: Social activism of persons with disabilities in Polanddevelopment and the current state of new social movements) czy Japonii i Korei. R. Takahashi $\mathrm{w}$ tekście: Universal and special conditions for advocating disability rights: from the experiences of Japan and Korea omawia czynniki rozwoju aktywnego i skutecznego rzecznictwa praw człowieka w Azji Wschodniej. W tym celu dokonuje przeglądu i porównania działań rzeczniczych organizacji osób niepełnosprawnych w Japonii i Korei. Anne-Lise Mithout natomiast w wystąpieniu, Aoi Shiba no Kai's strategy in Japanese society: uncompromising self-assertion at the risk of isolation?, prezentuje japoński ruch społeczny, kierowany przez grupę Aoi Shiba no Kai, który pojawił się w latach siedemdziesiątych domagając się społecznego uznania 
osób niepełnosprawnych i poszanowania ich praw człowieka. Ruch ten, kierowany przez grupę Aoi Shiba no Kai, wynikł z krytyki powszechnie uznawanej tolerancji społecznej dla dzieciobójstwa dzieci niepełnosprawnych i jednoczył się w potępianiu „eugeników”, wprowadzonych w ramach Ustawy o Ochronie Eugenicznej (1948-1996), umożliwiając na przykład sterylizację niepełnosprawnych kobiet, a z czasem przekształcił się z walki z "eugeniką" w narzędzie emancypacji i samopotwierdzenia osób niepełnosprawnych [Mithout 2017].

Badanie ruchów społecznych i aktywizmu odsyła badaczy w stronę pytań o społeczeństwo obywatelskie. Jak zauważa szwedzka badaczka M. Sepulchre, w swoim wykładzie na temat obywatelstwa i klasy społecznej T.H. Marshall zauważył, że "społeczeństwa, w których obywatelstwo jest rozwijającą się instytucją, tworzą obraz idealnego obywatelstwa, w stosunku do którego można mierzyć osiągnięcia i do którego dążenia można kierować". Ideał obywatelstwa nie jest jednak neutralny, a różni feministyczni badacze zwracają uwagę na to, że obywatelstwo ma tendencję do dostosowywania się do sytuacji osób pełnosprawnych, dorosłych, heteroseksualnych i pełnoetatowych mężczyzn. W konsekwencji osoby, które nie wypełniają tego szablonu, mogą znaleźć się w sytuacji „obywateli drugiej kategorii". Badaczka w swoim artykule przedstawia, w jaki sposób obywatelstwo jest stale wyobrażane, przerabiane i negocjowane na różnych płaszczyznach społecznych oraz jak ludzie domagają się prawa do uczestnictwa w społeczeństwie i uznania ich za wartościowych członków swojego społeczeństwa. Jej badanie koncentruje się na przypadku osób niepełnosprawnych w Szwecji, które domagają się prawa do pełnego obywatelstwa. Analiza empiryczna opiera się na internetowym blogu „Full Participation. Now!”, który powstał pięć miesięcy przed wyborami powszechnymi w Szwecji w 2010 r. (M. Sepulchre: Citizenship in action: Swedish disabled people claim "Full Participation. Now!", 2016).

A. Waldschmit, również rozpatruje pojęcie obywatelstwa, które jak podkreśla, jest szeroko stosowane przez działaczy na rzecz praw niepełnosprawnych i naukowców, którzy twierdzą, że niepełnosprawność jest przypadkiem nierówności społecznej i wskazują, że niepełnosprawni nie mają dostępu do pełnego obywatelstwa. Opierając się na obywatelstwie i prawach człowieka, międzynarodowy ruch na rzecz praw osób niepełnosprawnych opracował społeczny model niepełnosprawności, aby twierdzić, że usługi społeczne są prawami, a nie dobroczynnością. Konwencja ONZ o prawach osób niepełnosprawnych (2006) jest przełomowym wynikiem tej walki. Podobnie, uczeni zajmujący się niepełnosprawnością wykorzystują koncepcję obywatelstwa do badania sytuacji osób niepełnosprawnych w społeczeństwie. Jednak rzadko określają znaczenie obywatelstwa lub problematyzują sposób, w jaki obywatelstwo odnosi się do niepełnosprawności i jakie kwestie szczególne poruszane są w związku z tą relacją. Oczywiście istnieje potrzeba konceptualnej dyskusji na temat obywatelstwa i niepełnospraw- 
ności. Pojęcie obywatelstwa wiąże się z ambiwalentnymi aspektami niepełnosprawności. Z jednej strony obywatelstwo zapewnia jednostkom zestaw praw (politycznych, gospodarczych, społecznych i kulturalnych), które umożliwiają im uczestnictwo w społeczeństwie. Z drugiej jednak strony, obywatelstwo implikuje ideologię sprawności, czyli założenie, że obywatele powinni być zdrowi, racjonalni i autonomiczni (A. Waldschmit, Citizenship of / for Persons with Disabilities Re?ections on an Ambivalent Concept, 2017).

Kolejny z wątków tematycznych dotyczy rewizji dotychczasowych polityk wzgledem osób niepełnosprawnych. J.E. Andersson, w tekście: Our credo: full participation for all!, którego celem jest uczenie się z przeszłości w celu uzyskania większego wpływu w kształtowaniu polityki dotyczącej praw osób niepełnosprawnych w przyszłości, ową rewizję szwedzkiej polityki dotyczącej niepełnosprawności ukazuje [Andersson 2017]. W prezentowanych badaniach i eksploracjach, z punktu widzenia Crip Justice, osoby niepełnosprawne uważane są za grupę uciskaną i istnieje potrzeba walki o równość i włączenie. Obecność w społecznościach niepełnosprawności nie musi być postrzegana jako negatywna; coś, czego można żałować, lękać się, znienawidzić lub zdewaluować. Niepełnosprawność powinna być postrzegana jako cenny aspekt ludzkiej różnorodności, która przynosi wartość światu. „Sprawiedliwość dla niepełnosprawnych” jest wezwaniem do działania od wewnątrz, a nie do bierności. Crip Justice oznacza, że niesprawiedliwości wyrządzone osobom niepełnosprawnym stanowią pogwałcenie praw człowieka, zagrażających istnieniu osób niepełnosprawnych, stąd, można by rzecz ogólnoświatowy trend społecznego aktywizmu środowisk osób niepełnosprawnych.

\section{Relacje społeczne- społeczne rozpoznanie/rozumienie niepełnosprawności. Perspektywa indywidualna}

Kolejna płaszczyzna podejmowanych badań dotyczy relacji na styku pełno/ niepełnosprawność oraz wynikającej z niej indywidualnej perspektywy, indywidualnego/biograficznego doświadczenia niepełnosprawności. Prezentowane na konferencjach ALTER badania bardzo często ukazują światy życia codziennego osób z niepełnosprawnościami, doświadczenia biograficzne związane z uwikłaniem w niepełnosprawność, w danej społeczności i danej kulturze. Z owych doświadczeń buduje się obraz sytuacji tej grupy osób zarówno w europejskich krajach dobrobytu- dojrzałych demokracjach, ale także w krajach afrykańskich, azjatyckich czy komunistycznych, takich jak Rosja [The Making of Disability in Contemporary Russia, 2018] i Chiny. Z prezentowanych badań i analiz wynikają wspól- 
ne dla świata pełno i niepełnosprawnych problemy wykluczenia, adekwatności wsparcia, biedy i problemów z finansowych. Pojawia się także problem akceptacji i pewna ułuda integracji. Z ułudy integracji i niezadowolenia rodzą się ruchy społeczne, jak już wcześniej wspomniałam, które nie walczą tylko o prawa, ale o przeformułowanie aktualnej formy wspólnej egzystencji i uczynienie ją wolną od opresji. J.E. Andersson w tekście: Our credo: an inclusive society for all!, zwraca uwagę na konieczność pracy nie tylko nad dostępnością fizyczną, ale także mentalną. E. Hastbacka, przygląda się relacjom i miejscom osób niepełnosprawnych w Finlandii. Jak zauważa, uczestnictwo w różnych dziedzinach życia, takich jak rynek pracy czy rozrywka, jest ważne dla wszystkich. Doświadczenia z uczestnictwa społecznego dla osób niepełnosprawnych mogą jednak wpływać na różne rodzaje barier ograniczających uczestnictwo, a także na czynniki sprzyjające, które zwiększają uczestnictwo.

Dlatego uczestnictwo społeczne jest kamieniem węgielnym polityki w zakresie niepełnosprawności w Finlandii, a także na arenie międzynarodowej. Celem tego badania jest rzucenie światła na to, $\mathrm{w}$ jaki sposób osoby niepełnosprawne w Finlandii doświadczają własnego uczestnictwa społecznego (Hatsbacka: The experiences of societal participation of people with disabilities: An interviewstudy among people with disabilities in Finland, 2017). S. Schüpbach, V. Schuller, J. Bickenbach, B. Trezzini ukazują szwajcarską perspektywę niepełnosparwności. Szwajcaria ratyfikowała w 2014 r. Konwencję Narodów Zjednoczonych o prawach osób niepełnosprawnych (CRPD). Do tej pory stosunkowo niewiele jest badań na temat przeżywanych doświadczeń i działań osób niepełnosprawnych w Szwajcarii $\mathrm{w}$ odniesieniu do barier, z jakimi borykają się w różnych obszarach życia przez całe życie. Celem niniejszego badania było zidentyfikowanie strategii radzenia sobie $\mathrm{z}$ niepełnosprawnymi ludźmi $\mathrm{w}$ świetle barier utrudniających im pełne uczestnictwo i na równych warunkach z innymi w życiu dziedziny takie, jak edukacja, zatrudnienie, niezależne życie, korzystanie z technologii asystujących lub udział w życiu politycznym (Schüpbach, Schuller, Bickenbach, Trezzini: Being disabled in Switzerland: coping strategies of persons with impairments facing barriers to their participation in society, 2017).

Głównym nurtem badawczym w tym obszarze są badania sytucji życiowej, relacji $\mathrm{w}$ danej społeczności. W nim toczą się m.in. kolejne projekty badawcze: J. de Coster, Voices in the Dark: Congolese people with a physical disability in (in)visible Spaces. Autorka omawia część danych etnograficznych zebranych podczas badania antropologicznego w Belgii, w latach 2011-2015, dotyczących migrantów kongijskich z niepełnosprawnością jako nieobecnych, bezdźwięcznych czy niewidocznych „Innych”. Kolejni badacze obrazują sytuację codzienności osób z niepełnosprawnością w Etiopii, Szwecji, Malawi, Norwegii czy Indiach. N. Groce, Begging among Persons with Disabilities in Addis Ababa, Ethiopia; K. Engwall, Living together in 
opposition to norms and values of Swedish politics and everyday life - adults with ID living with their parents; Paul Lynch, Perspectives on difference and stigma: researching the lives of people with albinism in Malawi; Jan Tossebro, Growing up with disability in Norway-family perspectives; Vandana Chaudhry, A performative praxis for co-constructing knowledge as a disabled halfie in India.

Niezwykle ciekawe w kontekście indywidualnego doświadczenia i relacji ze społecznością wydają się badania Anna Margareth Kittelsaa dotyczące sytuacji osób z niepełnosprawnościami w Norwegii. Wystąpienie autorki, które jest w zasadzie pytaniem: Changes in services - changes in attitudes?, ukazuje zderzenie idealistycznych norweskich założeń reformy, Independent Living, lat 90. XX w. z rzeczywistością dnia dzisiejszego. Demontaż instytucji dla osób niepełnosprawnych intelektualnie w Norwegii nastąpił w wyniku reformy w latach 90 . Ideały reformy polegały na tym, że osoby z niepełnosprawnością intelektualną powinny mieszkać we własnych mieszkaniach, brać udział w życiu zawodowym lub innych zajęciach w ciągu dnia i prowadzić aktywne życie w wolnym czasie. Potrzebne wsparcie powinno być udzielane indywidualnie. Dzisiaj, jak pisze Kittelsaa, wydaje się, że te ideały zostały porzucone. Warunki życia są bardziej zinstytucjonalizowane, niewielu niepełnosprawnych jest $\mathrm{w}$ płatnej pracy, a wielu bierze udział w segregowanych zajęciach rekreacyjnych. Siłą napędową tego raczej negatywnego rozwoju mogą być na przykład: zmiany organizacyjne w gminach, mniej uwagi mediów, mniejsza siła wśród specjalistów i adwokatów, inne grupy w centrum uwagi.

Ponadto można zapytać, czy nowa sytuacja ma związek z postawami wobec osób niepełnosprawnych intelektualnie. Analizy wskazują, że nawet jeśli młode osoby chcą żyć tak, jak to nazywają zwykłym życiem, doświadczają barier z powodu negatywnych postaw zarówno osób, jak i organizacji [Kittelsaa 2016]. Podobny temat podejmuje R. Halvorsen, przyglądając się trajektoriom życia osób niepełnosprawnych, które to, w jej opinii, mogą zapewnić wgląd w instytucje społeczne i założenia kulturowe, które kształtują doświadczenia osób niepełnosprawnych i osób pełnosprawnych. Z socjologicznego punktu widzenia, jak zauważa, idea cyklu życia opisuje ważne wydarzenia i role, których ludzie doświadczają $\mathrm{w}$ czasie, na przykład powiązane $\mathrm{z}$ edukacją, pracą i zatrudnieniem, zakładaniem oddzielnego gospodarstwa domowego, małżeństwem, rodzicielstwem i emeryturą. W swoich badaniach analizuje, w jaki sposób doświadczenia osób niepełnosprawnych mogą być powiązane ze zmieniającymi się instytucjonalnymi warunkami pełnego i skutecznego uczestnictwa w społeczeństwie. Ukazuje powiązania i relacje między przeżywanymi doświadczeniami osób niepełnosprawnych a reformami polityki społecznej, które mają wpływ na ich życie (R. Halvorsen, Connecting lived lives and disability policy change in Europe - outline of a theoretical strategy, 2017). 
Badania relacji społecznych, to także spojrzenie na nie z perspektywy osób $\mathrm{z}$ niepełnosprawnościami. To poznanie indywidualnej perspektywy, w kontekście identyfikacji własnej tożsamości. Kim jestem w tym świecie, jak jestem przez ten świat definiowany? W europejskich studiach nad niepełnoprawnoscią ta indywidualna perspektywa i sięgniecie do doświadczeń i głosów osób z niepełnosparwnościami jest obecne. A. Gustavsson w swoich rozważaniach szuka nowego teoretycznego zrozumienia budowy tożsamości osób z niepełnosprawnością intelektualną. Analiza, zawarta w tekście, opiera się zarówno na przeglądzie literatury w dziedzinie, jak i na dokładnych odczytach czterech historii życia młodych dorosłych mówiących o osobistym doświadczeniu niepełnosprawności intelektualnej (A. Gustavsson, Complexity and Continuity-identity constructions of persons with intellectual disabilities, 2016).

D. Krzemińska, I. Lindyberg koncentrują się na zjawisku bycia dorosłym z niepełnosprawnością intelektualną w kontekście uczestnictwa, włączenia / wykluczenia i tworzenia znaczeń. Ukazują rekonstrukcję doświadczeń uczestników jako dorosłych i znaczeniach przypisywane przez dorosłych z niepełnosprawnością intelektualną koncepcji dorosłości, to w jaki sposób rozumieją i definiują swoje indywidualne doświadczenia biograficzne z dorosłością i niepełnosprawnością. Prezentowane analizy odnoszą się do wybranej grupy osób dorosłych z niepełnosprawnością intelektualną, uczestników polskich warsztatów terapii zajęciowej i domów pomocy społecznej, funkcjonujących w ramach współczesnego polskiego systemu wsparcia społecznego dla osób niepełnosprawnych. W kontekście tych badań integracja społeczna i włączenie społeczne są nie tylko ważnymi ideami i prawami człowieka, ale w znacznym stopniu wpływają na jakość życia dorosłych z niepełnosprawnością intelektualną, zapewniając lepsze bezpośrednie i dostosowują wsparcie społeczne w doświadczeniu dorosłości, odpowiednio / lub nie na ich potrzeby, oczekiwania i indywidualne umiejętności (D. Krzemińska, I, Lindyberg, Individual concepts and experiences of adulthood of people with intellectual disabilities in the context of inclusion/exclusion, participation and human rights, 2016). B.M. Leonor i L. Cláudia w tekście: Voices of young adults with disability przedstawiają wyniki wciąż trwających badań eksploracyjnych, które zgromadziły świadectwa młodych osób niepełnosprawnych. Badanie ma na celu zrozumienie ich percepcji i doświadczeń dotyczących ich włączenia społecznego, z naciskiem na edukację szkolną, integrację zawodową i zajęcia rekreacyjne [Leonor, Claudia 2017]. 


\section{Społeczno-kulturowe konstrukcje niepełnosprawności. Reprezentacje niepełnosprawności w mediach, literaturze i dyskursie publicznym}

Następny z wyodrębnionych przeze mnie obszarów badawczych europejskich studiów nad niepełnosprawnością to badania lokujące się głównie w kulturowym modelu niepełnosprawności. Modelu kulturowym, który jak powyżej to opisałam rozpatruje niepełnosprawność i normalność jako efekty generowane przez wiedzę akademicką, środki masowego przekazu i codzienne dyskursy. Inaczej mówiąc, w myśl tego modelu, niepełnosprawność postrzegana jest jako zjawisko społeczne bezustannie konstruowane $\mathrm{w}$ i przez dyskurs, praktyki interpretacyjne i praktyki działania obecne $\mathrm{w}$ codziennym życiu, w społecznych mechanizmach "radzenia sobie z niepełnosprawnością". Z owych dyskursywnych praktyk, praktyk działania i praktyk interpretacyjnych wynikają społeczne rozpoznania niepełnosprawności, społeczne znaczenia jej przypisywane oraz społeczne relacje. Uznając ten fakt, badacze europejscy szukają w swoich eksploracjach odpowiedzi na pytania o dyskursywne reprezentacje niepełnosprawności, o medialne wizerunki, o sposoby konstruowania niepełnosprawności w bajkach i filmach.

Jeden z wątków badawczych tego nurtu dotyczy właśnie analiz wizerunków niepełnosprawności kreowanych w filmach czy bajkach i opowiadaniach. Owe wykreowane wizerunki ukazują społeczne sposoby widzenia niepełnosprawności, ale również są narzędziem społecznej reprodukcji, dalszego powielania obrazu/znaczeń niepełnosprawności w społecznej świadomości. R. Kitchen szuka odpowiedzi na pytanie, jak w filmach dokumentalnych XXI w. prezentowana jest tematyka osób niesłyszących. Dostarcza ona informacji na temat ewoluującego społecznego zrozumienia osób niesłyszących i obecności głuchoty w domenie publicznej (R. Kitchen, Theorizing Social Understandings and Representations of Deafness and Deaf People through Cinema, 2017). M. Apelle, w swoich analizach ukazuje obraz niepełnosprawności zawarty w bajkach Grimm (Think handicap with Grimm's Fairy Tales, 2016). Autorka przedstawia 87 takich portretów odnalezionych w 200 bajkach. Bajkach, które czytane dzieciom, wpływają na ich późniejsze postrzeganie niepełnosprawności. J. Wälivaara bada i analizuje najnowszy dodatek do serii Star Wars, Rouge One (2016), w odniesieniu do portretów i stereotypów dotyczących niepełnosprawności $\mathrm{w}$ popularnym kinie. Prezentowana analiza odbywa się w perspektywie feministycznej, queerowej i przyczynia się do rozwoju badań nad kinem i reprezentacjami niepełnosprawności. Rozważania badaczki opierają się na założeniu, że normatywność jest tworzona i (re)produkowana w negocjacjach między społeczeństwem a kulturą, w tym historiami wytworzonymi i skonsumowanymi przez jej mieszkańców. O ile popularność popularnego filmu można 
uznać za wyraz współczesnych norm, można je również postrzegać jako współtwórców tych norm i naszego rozumienia teraźniejszości. Film i telewizja mają zatem wpływ na społeczeństwo i jego normy (J. Wälivaara, "I am one with the Force and the Force is with me": Depictions of Disability and Sexuality in Rouge One, 2017). Film jest również doskonałym narzędziem zmiany społecznej świadomości i w takim kontekście prezentowany jest projekt D. Gariglio, Archetypes or stereotypes? Representing people with intellectual disability, the case of VelaSpiegata webserie. Projekt związany jest z tworzeniem nowej świadomości społecznej o osobach z niepełnosprawnością intelektualną. Powstał aby odwrócić reprezentację osób z niepełnosprawnościami, aby zmienić ich stereotyp, jako infantylnych, niesamodzielnych i niedorosłych. Projekt to 10 filmowych odcinków, to opowieść o niezależnej ścieżce życia dwóch młodych dorosłych [Gariglio 2017].

Inny wątek badawczy związany jest ściśle z językiem i dyskursem. Badacze analizują jakim językiem mówi się o niepełnosprawności, w jaki sposób język i znaczenia przez niego tworzone budują społeczną reprezentację niepełnosprawności. I. Norberg w swoich badaniach prezentuje czy i w jaki sposób osoby niepełnosprawne i niepełnosprawność są reprezentowane politycznych szwedzkich debatach (Representations of disability in Swedish political debates, 2015). Jan Grue (Now You See It, Now You Don't: Disability Studies in a Disciplinary World, 2016), odnosząc się do poststrukturalnych teorii dyskursu oraz koncepcji Disability Studies, pyta w jaki sposób koncepcja niepełnosprawności i niepełnosprawności jako kategorii jest tworzona w różnych kontekstach wiedzy, oraz jako odpowiedni efekt społecznych i politycznych praktyk. Niezwykle ciekawe badania, dotyczące mowy nienawiści względem osób niepełnosprawnych zaprezentowali J.S. Vedeler, T. Olsen. Odnosząc się do brytyjskich i amerykańskich badań nad zjawiskiem mowy nienawiści i niepełnosprawności pokazują, że osoby niepełnosprawne są celem przemocy na tle nienawiści i przestępstw z nienawiści w większym stopniu niż inni obywatele. Bycie ofiarą mowy nienawiści może powodować poważne problemy osobiste, a także ograniczenia w życiu ludzi. Co więcej, mowa nienawiści może stworzyć sytuację polityczną „ucisku wyciszającego”, w której poszczególne grupy obywateli wycofują się z udziału społecznego w obawie przed piętnowaniem i dyskryminowaniem wypowiedzi i praktyk. W krajach skandynawskich jak dotąd nie badano i nie rozważano występowania i doświadczeń związanych z mową nienawiści wobec osób niepełnosprawnych. Nasze badanie analizuje następujące trzy pytania: W jakim stopniu osoby niepełnosprawne są narażone na mowę nienawiści? Jakie rodzaje mowy nienawiści odczuwają i w jakich kontekstach oraz jakie są konsekwencje doświadczania takich wypowiedzi? Jakie środki zapobiegawcze można wdrożyć? [J.S. Vedeler, Olsen, Hate speech targeted at disabled persons, 2016]. 


\section{Polityka zatrudnienia i system wsparcia aktywności zawodowej}

Prawo do pracy jest jednym z praw zapisanych w art. 27 Konwencji ONZ, bycie zatrudnionym to droga do samodzielnego życia. W wielu krajach prowadzona jest polityka zatrudnienia zwiększającą szansę na aktywność zawodową różnym grupom osób niepełnosprawnych. Badacze zajmujący się tą problematyką analizują politykę zatrudnienia poszczególnych krajów, ukazują funkcjonowanie sytemu wsparcia aktywności zawodowej, odsłaniają specyfikę danego państwa i instrumenty lokalnych rynków pracy. Szukają przyczyn niskiego wskaźnika zatrudnienia osób niepełnosprawnych, ale także ukazują sposoby realizacji nowych form wsparcia zatrudnienia takich jak: zatrudnienie wspomagane. W analizach nie brakuje krytycznego spojrzenia na realizację prawa do zatrudnienia w kontekście realizacji postanowień Konwencji ONZ.

Badacze eksplikujący projekty dotyczące doświadczeń aktywności zawodowej osób niepełnosprawnych odnoszą je do perspektywy praw człowieka pokazując, że istniejący system tworzy nową hierarchię wykluczenia społecznego wśród osób niepełnosprawnych, pozostawiając w szczególności osoby z niepełnosprawnością intelektualną, autyz- mem i chorobami psychicznymi na marginesie wykluczonych (A. Woynarowska, The employment policy and vocational activity support system for people with intellectual disabilities in Poland: life politics, emancipation or apparent actions?, 2018; Marie-Renée Guével, Barriers and facilitators to access paid jobs, 2016). A silny nacisk polityczny, jaki kładzie się na włączenie do pracy i zatrudnienia, staje się przeszkodą dla wielu niepełnosprawnych $w$ realizacji ich rzeczywistych możliwości i potrzeb. Takie krytyczne wnioski widoczne są w badaniach m.in. E. Fiala, których celem jest prześledzenie instrumentów systemu wsparcia i polityki obecnie stosowanych w celu wspierania włączenia osób niepełnosprawnych do pracy i zatrudnienia. Jak pisze, włączenie do pracy i zatrudnienia, a dokładniej włączenie do otwartego rynku pracy stało się kluczową walką w ostatnich podejściach politycznych dotyczących ogólnego włączenia osób niepełnosprawnych w kontekście niemieckim. W przeszłości praca osób niepełnosprawnych była głównie rozwiązywana $w$ ustalonym oddzielnym systemie, naznaczonym przez chronione miejsca pracy i specjalne ośrodki szkoleniowe dla różnych rodzajów niepełnosprawności. W szczególności od czasu ratyfikacji Konwencji ONZ o prawach osób niepełnosprawnych, system ten był coraz częściej kwestionowany. Argumentowano, że system segregacji wspiera wykluczenie społeczne osób niepełnosprawnych (E. Fiala, A new hierarchy of disability? A critical analysis of the implementation of the right to work and employment in the national context of Germany, 2017). 
J.M. Nogueira prezentuje politykę zatrudnienia osób niepełnosprawnych $\mathrm{w}$ Portugalii, gdzie prawo do niedyskryminacji w zatrudnieniu jest zapisane $\mathrm{w}$ ustawodawstwie krajowym. Portugalia ma również konkretne aktywne środki na rzecz zatrudnienia osób niepełnosprawnych. Badania analizują rolę aktywnych instrumentów zatrudnienia, główne bariery utrudniające udział w rynku pracy oraz wkład organizacji osób niepełnosprawnych i ich rodzin w aktywizacji zawodowej (J.M. Nogueira, The myths and the facts of disability and work in Portugal, 2015). D. Ondrusova analizuje politykę zatrudnienia poszczególnych krajów Unii Europejskiej (Overview of the policies implemented, 2016). J. Tøssebro, natomiast, ukazuje działania głównej federacji pracodawców w Norwegii, która to uruchomiła inicjatywę i strategię łączącą usługi rehabilitacji zawodowej z firmami członkowskimi w celu ułatwienia rekrutacji osób niepełnosprawnych i innych grup mających problemy na rynku pracy (J. Tøssebro, Employer federation's initiative to promote employment among disabled people, 2017).

Inny wątek tematyczny w badaniach aktywności zawodowej oscyluje wokół praktyk działania poszczególnych firm zatrudniających osoby niepełnosprawne, kultury organizacji miejsc pracy, realizacji projektów zatrudniania wpomaganego (Gustafsson, Supported employment and social inclusion at the workplace, 2018; A. Woynarowska, I. Lindyberg, Supporting vocational activity of people with intellectual disability in Poland, 2015), czy dostępności i dostosowań rynku pracy (Schreuer, How do employees with ASD and their employers perceive workplace accessibility?, 2018). J.E. Uhasselt, P.Z. Uhasselt podkreślają, że najnowsze badania sugerują, iż doświadczenia zawodowe niepełnosprawnych pracowników mogą być kształtowane przez kulturę organizacyjną danej firmy. Do chwili obecnej przeprowadzono niewiele badań na ten temat, które wykraczają poza teoretyczne założenia i uproszczone podziały między biurokratycznymi i elastycznymi organizacjami. Badacze dokonują dogłębnej analizy wielu przypadków w trzech belgijskich firmach, które są postrzegane jako „najlepsze przypadki” w zakresie zatrudniania osób niepełnosprawnych. Porównując unikalne zestawy praktyk dotyczące niepełnosprawności i podstawowych znaczeń odkrywają różne możliwości konstrukcji tożsamości pracowników z niepełnosprawnością (Uhasselt, Disabled employees: identity work within organizational disability regimes: a study of 3 Belgian cases, 2017). Badania A. Wegscheider i S. Breinlinger koncentrują się na ostatnich zmianach w polityce rynku pracy, ze szczególnym uwzględnieniem wspieranych programów zatrudnienia. Badaczki porównują wspierane polityki zatrudnienia i programy w Szwecji, Niemczech, Holandii, Wielkiej Brytanii i Austrii (Different Developments in Supported Employment policies, 2017). 


\section{Ciało, płeć, seksualność}

Ostatni obszar badań w europejskich studiach nad niepełnosprawnością, który chciałabym omówić, odnosi się do ciała/cielesności, płci i seksualności. W perspektywie antropologii kulturowej ciało jest postrzegane jako odbiorca społecznych znaczeń i symboli, jako metafora społeczeństwa [Douglas 1966, 1970]. Symboliczny interakcjonizm traktuje ciało jako komponent działania jednostek, ciało pośredniczy w relacjach między tożsamością osobistą i społeczną [Goffman 2007], poststrukturalizm uznaje ciało jako „obiekt” kontrolowany przez dyskursy. Dyskursy kontrolują ciało pośrednio przez konstrukcję „świadomego ciała”, definiowanego poprzez świadomość, intencję i język [Foucault 1984].

P. Bourdieu pisze o ciele jako zjawisku materialnym i nośniku symbolicznych znaczeń. Ciało jest formą kapitału fizycznego, nośnikiem władzy, społecznego statusu i form symbolicznej dystynkcji niezbędnych w procesie akumulowania rozmaitych zasobów [Bourdieu 1998]. E. Gardien, w swoich badaniach: Peer counsellors' resistance to ability-centrism : a way for body emancipation, zwraca uwage, że główne ruchy na rzecz niepełnosprawności skupiają się na poglądach politycznych w temacie niepełnosprawności. Walczy się o dostępność, jak i prawa człowieka. Ich głównym celem jest zmiana społeczna. To jest powód, dla którego ciało jest prawie zapomniane. Badania „niepełnosprawnego, nienormatywnego, crip ciała” odnoszą się do relacji w sztuce, do możliwości porzucenia „niepełnowartościowości” w akcie twórczym. S. Bocchini ukazuje project „Niepełnosprawność na scenie". žródłem i inspiracją dla tych badań były prace m.in. P. Kuppers, C. Sandahl, O. Smith, R. Garland -Thomson i T. Siebersa. Jak prezentuje Bocchini, w listopadzie 2015 r. sześciu niepełnosprawnych wykonawców Compagnia Teatro Danz Abile (Lugano, Szwajcaria) i ośmiu magistrantów w Accademia Teatro Dimitri (Verscio, Szwajcaria) spotkało się podczas dwutygodniowych warsztatów teatralnych, które nawiązywały do szerszego projektu badawczego „Niepełnosprawność na scenie”, prowadzonego przez Zürcher Hochschule der Künste. Praktyczne warsztaty miały być kluczowym momentem do zbadania powiązań między teatrem a teatrem stworzonym przez niepełnosprawnych wykonawców (Bocchini, Disabled body in discourse, 2017).

Seksualność w odniesieniu do ciała, możliwość jej realizacji oraz ekspresji, a także tożsamość płci to bardzo istotny nurt badawczy, który realizowany jest w płaszyźnie Queer Disability Studies. Pierwsze prace poświęcone queer disability studies pojawiły się w latach $90 . \mathrm{XX}$ w. ${ }^{2}$ Teoria i praktyka queer disability studies sku-

\footnotetext{
Zob. E. Clare, Exile and Pride: Disability, Queerness, and Liberation, 1999; S. Tremain, Pushing the Limits, Disabled Dykes Produce Culture, 1996; V.A. Brownworth, S. Raffo, Restricted Access, Lesbians on Disability, 1999; R. McRuer, A.L. Wilkerson, Desiring Disability, Queer Theory Meets Disability Studies, 2003.
} 
pia się nie tylko na osobach doświadczających dyskryminacji wielokrotnej ze względu na orientację seksualną i niepełnosprawność, ale zdecydowanie bardziej na poszukiwaniu wspólnych dla tych ruchów emancypacyjnych przyczyn i kategorii wykluczeń oraz na wspólnych strategiach walki. R. McRuer w odniesieniu do queer disability studies używa terminu crip theory, gdzie słowo, crip' (podobnie jak sformułowanie , queer') pierwotnie było (i jest) określeniem obelżywym wobec osób z różnymi niepełnosprawnościami. $\mathrm{W}$ refleksjach na temat sytuacji osób nieheteroseksualnych i z niepełnosprawnościami podkreśla się ich nienormatywność. Jedna i druga kategoria została w przeszłości zdefiniowana w paradygmacie medycznym jako patologia i choroba, w kategoriach społecznych - jako odmieńcy. Wspólnym dla osób nieheteroseksualnych i z niepełnosprawnościami obszarem wykluczeń pozostaje ciało i seksualność - dwa obszary nieodłącznie ze sobą powiązane. Dominująca definicja zdrowego, sprawnego i pięknego ciała zdolnego do tzw. normalnego pożądania i normalnego aktu seksualnego stygmatyzuje osoby queer i niepełnosprawne jako niekompletne, słabe i dziwaczne. Studia poświęcone queer i niepełnosprawności analizują $\mathrm{w}$ jaki sposób społeczeństwo w nieustanny sposób reprodukuje te wykluczające normy i w jaki sposób się one przejawiają [McRuer 2003; Goodley 2011, za: Chusteczka].

Wśród badań podejmowanych przez europejskich badaczy, w obszarze ciała, płci i seksualności, prezentowanych na konferencjach Alter dostrzegam następujące wątki badawcze: pierwszy o asystentach seksualnych i ułatwieniach w ekspresji seksu dla osób z niepełnosprawnościami (Can Prostitution be Cripped? Organizing Sexual Assistance for People with Disabilities in Europe, G. Geymonat; Accompany, educate, liberate. An interdisciplinary study on sexual assistance for people with disabilities, A. Magnanini; Sexuality: a risk or a right? Conceptualisations of sexual expression by personnel in disability services, J. Bahner). Jak zauważają badacze, pomoc seksualna to termin określający szeroki zakres bezpośredniego wsparcia seksualnego dla osób niepełnosprawnych. Mimo że pomoc seksualna, pod różnymi nazwami, była widoczna w Europie przynajmniej od lat 90 . XX w., dopiero niedawno stała się przedmiotem dużej uwagi politycznej i medialnej, produkcji filmowej, a także badań naukowych, chociaż w praktyce jest ograniczona. W tej dziedzinie konflikty wokół wyzysku, autonomii, nadużyć, komercjalizacji, stygmatyzacji stały się tak gwałtowne, jak w przypadku prostytucji - praca seksualna. W rzeczywistości pomoc seksualna jest traktowana przez prawo głównie jako forma prostytucji, ponieważ obejmuje bezpośredni kontakt seksualny i wynagrodzenie za usługi. Co więcej, wyjątkowe ryzyko medykalizacji i dyscypliny okazuje się kluczowe w pomocy seksualnej, a dyskurs publiczny ma tendencję do reprodukowania niepełnosprawnego ciała jako wyjątkowego i niepożądanego. Kiedy jednak przyjrzymy się praktykom, okazuje się, że pomoc seksualna stanowi całkiem oryginalną przestrzeń społeczną, zwłaszcza w zakresie społecznej 
organizacji praktyk, znaczeń, a zatem procesów stygmatyzacyjnych i zrozumienia konfliktów społecznych. Geymonat pyta, co się dzieje z prostytucją, gdy jest rozumiana jako zaangażowanie aktywistów? [Geymonat 2015]. Od końca lat 90. XX w. pomoc seksualna dla osób niepełnosprawnych była systematycznym tematem wielu badań na poziomie międzynarodowym. Obecnie prawo do seksualności osób niepełnosprawnych stało się wyłaniającym problemem sprawiedliwości społecznej, a sama seksualność jest niezbywalnym prawem [Magnanini 2015]. Większość ludzi stosuje się do zrozumienia seksualności jako podstawowej ludzkiej potrzeby, która obejmuje prawo do ekspresji seksualnej i zdrowia seksualnego. Jednakże seksualność osób niepełnosprawnych jest często lekceważona zarówno w kontekście kulturowym, jak i w zakresie usług dla osób niepełnosprawnych, gdzie personel często nie ma wystarczających kompetencji, aby móc radzić sobie z ekspresją seksualną w sposób niedyskryminujący. Badania Bahner, dotyczą myśli i doświadczeń personelu w szwedzkich serwisach pomocy osobistej dotyczących ekspresji seksualnej w pracy z osobami niepełnosprawnymi ruchowo [Bahner 2016].

Drugi wątek badawczy, tego obszaru, dotyczy doświadczania kobiecości i macierzyństwa przez niepełnosprawne intelektualnie kobiety (Quand Gender et Disability studies ne se rencontrent pas?, Ch. Gruson). Badania poruszają problematykę społecznych doświadczeń związanych z macierzyństwem kobiet, które zostały oznaczone jako „upośledzone umysłowo” oraz są w sytuacji wsparcia instytucjonalnego. We Francji i za granicą ruchy kobiece i stowarzyszenia feministyczne zwracały niewielką uwagę na problem kobiet niepełnosprawnych. Co więcej, specyfika niepełnosprawnych kobiet jest bardzo rzadko brana pod uwagę w polityce i działaniach na rzecz osób niepełnosprawnych i kobiet w ogóle. Okazuje się jednak, że wszystkie badania potępiają podwójną dyskryminację doświadczaną przez kobiety niepełnosprawne. Badania pokazują, że kobiety niepełnosprawne są dwa razy częściej niż kobiety bez niepełnosprawności narażone na przemocy i seksualne "wykorzystywania” w swoim życiu. Pomijanie kobiet niepełnosprawnych $w$ dyskursach feministycznych zaciemnia większość ich doświadczeń społecznych, nawet bez zamiaru dyskryminowania. Izolacja kobiet niepełnosprawnych przyczynia się do tego, że ich doświadczenia społeczne i ekonomiczne nie prowadzą do nowego i innowacyjnego myślenia [Gruson 2017].

Trzeci obszar badań dotyczy przemocy wobec kobiet (Out of the shadows: Uncovering violence against women and girls with disabilities in Portugal, P. Campos Pinto, 2016). Jak omawia sytuację przemocy, P. Campos Pinto, kobiety niepełnosprawne stają w obliczu wielu warstw dyskryminacji. Są dyskryminowane ze względu na swoją niepełnosprawność, a także ze względu na płeć. Ponadto kobiety niepełnosprawne stanowią zróżnicowaną i niejednorodną grupę - wiele z nich może również spotkać się z dodatkowymi uprzedzeniami i napiętnowaniem ze względu na rasę, pochodzenie etniczne, preferencje seksualne, wiek i inne aspekty tego, kim 
są i jak żyją. Ta dyskryminacja wielokrotna jest wyraźnie uznana w Konwencji ONZ o prawach osób niepełnosprawnych, która w artykule 6 zobowiązuje Państwa-strony do „podjęcia wszelkich odpowiednich środków w celu zapewnienia pełnego rozwoju, rozwoju i wzmocnienia pozycji kobiet". Niezależnie od tego zobowiązania, międzynarodowe badania naukowe wykazało, że kobiety niepełnosprawne są jeszcze bardziej ofiarami przemocy lub gwałtu niż kobiety sprawne i mniej prawdopodobne jest, że będą w stanie uzyskać interwencję policji, ochronę prawną lub odpowiednią opiekę [Pinto 2016].

Kolejny wątek badawczy odnosi się do równości płciowej, a także transpłciowych osób z niepełnosprawnością (Ann Frisell Ellburg: A gender equality analysis of living conditions and participation opportunities for persons with disabilities; Claire Lucille Azzopardi Lane: A minority within a minority: Being transgender and having an intellectual disability). Szwedzka Agencja ds. Uczestnictwa przeprowadziła analizę płci. Jej celem, jak prezentuje A. Ellburg, było przeprowadzenie dogłębnych analiz i określenie różnic w poziomie płci dotyczących warunków życia, możliwości uczestnictwa dla osób niepełnosprawnych oraz ich dostępu do różnego rodzaju wsparcia ze strony władz. Badanie koncentruje się na obszarze edukacji, rynku pracy, wpływie politycznym i zdrowiu, zgodnie z celami polityki równości płci obecnego rządu [Ellburg 2017]. Tożsamość seksualna i ekspresja seksualna są integralnymi częściami życia danej osoby, a osoby niepełnosprawne nie są wyjątkiem. Jednak osoby niepełnosprawne są narażone na uprzedzenia, napiętnowanie i dyskryminację przy wyrażaniu nieheteronormatywnej tożsamości seksualnej. C. Lane w swoich badaniach opisuje doświadczenia młodej osoby z niepełnosprawnością intelektualną, która identyfikuje się jako osoba transpłciowa w maltańskim kontekście społeczno-kulturowym. Badania wskazują na brak świadomości i akceptacji osób niepełnosprawnych, które identyfikują się jako LGBTQI, wśród członków rodziny, specjalistów i usługodawców, a także w lokalnej społeczności. Czynniki te prowadzą do lęku i ignorancji, które przyczyniają się do barier napotykanych przez osoby niepełnosprawne podczas wyrażania swojej tożsamości seksualnej. Bycie mniejszością w mniejszości przyczynia się do dalszego naruszania praw człowieka osób niepełnosprawnych, które identyfikują się jako LGBTQI, a tym samym z możliwości pełnego uczestnictwa w społeczeństwie. Tak więc osoby niepełnosprawne wymagają dalszego wsparcia ze strony organizacji promujących prawa społeczności LGBTQI [Lane 2017]. Badacze podejmują także wątki prawa do seksualności, prawa do bycia osobą seksualną (J. Bahner, Sexuality: a measure for citizenship and inclusion, 2017). Zgodnie z globalnym raportem Światowej Organizacji Zdrowia (WHO) i Funduszu Ludnościowego Narodów Zjednoczonych (UNPF), zdrowie seksualne i reprodukcyjne oraz prawa osób niepełnosprawnych są często lekceważone. Jednym z powodów tych zmagań i braku zainteresowania kwestiami seksualnymi dotyczącymi osób niepełnosprawnych 
są ogólne tabu związane z tematem; konsekwencje takie jak niewystarczająca kompetencja dla odpowiednich specjalistów oraz brak reprezentacji, a raczej wprowadzanie w błąd w polityce społecznej, mediach i kulturze. Seksualność to szeroki temat, obejmujący takie zagadnienia, jak zdrowie, prawa seksualne i reprodukcyjne (SRHR), tożsamości seksualne i orientacje seksualne oraz zaangażowanie seksualne. Ważną kwestią jest potencjalne profesjonalne wsparcie potrzebne osobom niepełnosprawnym, aby móc wyrazić swoją seksualność zgodnie z życzeniem lub osiągnąć adekwatne zdrowie seksualne i dobre samopoczucie. Seksualność jest środkiem na rzecz obywatelstwa i integracji w społeczeństwie. Społeczeństwie, które dąży do integracji i jest dostępne dla wszystkich ludzi [Bahner 2017].

\section{Zakończenie}

Przedstawione $\mathrm{w}$ niniejszym artykule nurty, wątki badawcze oraz obszary czy płaszczyzny badań europejskich studiów nad niepełnosprawnością, badaczy zrzeszonych w ALTER - European Society for Disability Research, charakteryzują się wielowątkowością i zróżnicowaniem postrzegania niepełnosprawności. Zjawisko niepełnosprawności omawiane przez historyków, socjologów, antropologów, kulturoznawców, teatrologów, psychologów czy filozofów postrzegane jest z perspektywy kulturowego modelu niepełnosprawności oraz płaszczyzny Disability Studies i Critical Disability Studies. Przyglądając się badaniom prowadzonym przez badaczy zjawiska niepełnosprawności w Europie i na świecie, uczestnicząc w konferencjach Alter nasuwa się refleksja dotycząca wspólnoty problemów i podobieństw, pomimo różnych kontekstów kulturowych. Analiza wątków badawczych to doskonała sposobność do poznania sposobów konceptualizacji zjawiska niepełnosprawności, a poszukiwanie i odkrywanie nowych teorii dla interpretacji otaczającej nas rzeczywistości, w której niepełnosprawność zajmuje stałe miejsce, może być źródłem inspiracji dla naszych, polskich badań nad niepełnosprawnością.

\section{Bibliografia}

Andersson J.E. (2017), Norwegian and Swedish disability policies in action, https://alterconf 2017.sciencesconf.org/data/pages/Book_alterconf2017_fr.pdf.

Andersson J.E. (2017), Our credo: full participation for all!, https://alterconf2017.sciencesconf. org/data/pages/Book_alterconf2017_fr.pdf.

Andersson J.E. (2017), Our credo: an inclusive society for all!, https://alterconf2017.sciencesconf.org/data/pages/Book_alterconf2017_fr.pdf. 
Andersson J.E., Balke, Skehan (2016), Dissecting strategies for creating inclusive societies in twelve western countries, going beyond accessibility concepts and achieving universal usability, https://alterconf2016.sciencesconf.org/data/pages/book_alterconf2016_3sept.pdf.

Andersson J.E. (2017), Nordic operationalisation of rights for people with disabilities: accessibility, inclusion, and the UNCRPD put in action in Norway and Sweden, https://alterconf2017. sciencesconf.org/data/pages/Book_alterconf2017_fr.pdf.

Apelle M. (2015), Think handicap with Grimm's Fairy Tales, https://alterconf2015.sciencesconf.org/conference/alterconf2015/pages/Livret.pdf.

Armstrong F. (2015), Disability, education and participation: a critical analysis of recent policy developments in England, https://alterconf2015.sciencesconf.org/conference/alterconf2015/ pages/Livret.pdf.

Arenas-Conejo M. (2015), The committees of functional diversity in the $15 \mathrm{M}$ movement: reformulating disability activism in Spain, https://alterconf2015.sciencesconf.org/conference/alterconf2015/pages/Livret.pdf.

Attia M. (2015), Egyptian Disability Movement: Are Voices Heard and Policies Impacted?, https:// alterconf2015.sciencesconf.org/conference/alterconf2015/pages/Livret.pdf.

Bahner J. (2016), Sexuality: a measure for citizenship and inclusion, https://alterconf2016.sciencesconf.org/data/pages/book_alterconf2016_3sept.pdf.

Bocchini (2017), Disabled body in discourse, https://alterconf2017.sciencesconf.org/data/pages/Book_alterconf2017_fr.pdf.

Bourdieu P. (1998), La domination masculine, coll. Liber, Paris.

Byrne B. (2016), Rights-Holders under the UNCRPD: Challenging De?nitions of Disability in Human Rights, https://alterconf2016.sciencesconf.org/data/pages/book_alterconf2016_3sept.pdf.

Chaudhry V. (2016), A performative praxis for co-constructing knowledge as a disabled halfie in India, https://alterconf2016.sciencesconf.org/data/pages/book_alterconf2016_3sept.pdf.

Chustecka M. (2018), Queer Disability Studies, https://rownosc.info/dictionary/queer-disability-studies [dostęp: 10.11.2018].

Coster J. (2017), Voices in the Dark: Congolese people with a physical disability in (in)visible Spaces, https://alterconf2017.sciencesconf.org/data/pages/Book_alterconf2017_fr.pdf.

Doat D. (2016), Which teory of Disability does transhumanism presuppose?, https://alterconf2016. sciencesconf.org/data/pages/book_alterconf2016_3sept.pdf.

Douglas M. (1966), Purity and Danger. An Analysis of Concept of Pollution and Taboo, Wydawnictwo Routledge, London-New York.

Ellburg, Friesel A. (2016), A gender equality analysis of living conditions and participation opportunities for persons with disabilities, https://alterconf2016.sciencesconf.org/data/pages/ book_alterconf2016_3sept.pdf.

Engwall K. (2016), Living together in opposition to norms and values of Swedish politics and everyday life - adults with ID living with their parents, https://alterconf2016.sciencesconf.org/data/ pages/book_alterconf2016_3sept.pdf.

Fiala (2017), A new hierarchy of disability? A critical analysis of the implementation of the right to work and employment in the national context of Germany, https://alterconf2017.sciencesconf. org/data/pages/Book_alterconf2017_fr.pdf.

Foucault M. (1984), Historia seksualności, Éditions Gallimard. 
Gardien (2017), Peer counsellors' resistance to ability-centrism: a way for body emancipation, https://alterconf2017.sciencesconf.org/data/pages/Book_alterconf2017_fr.pdf.

Gariglio D. (2017), Archetypes or stereotypes? Representing people with intellectual disability, the case of VelaSpiegata webserie, https://alterconf2017.sciencesconf.org/data/pages/Book_alterconf2017_fr.pdf.

Geymonat G. (2015), Can Prostitution be Cripped? - Organizing Sexual Assistance for People with Disabilities in Europe, https://alterconf2015.sciencesconf.org/conference/alterconf2015/ pages/Livret.pdf.

Geymonat G. (2017), Accompany, educate, liberate. An interdisciplinary study on sexual assistance for people with disabilities, https://alterconf2017.sciencesconf.org/data/pages/Book_alterconf2017_fr.pdf.

Ginsburg F., Rapp R. (2016), Cripping the future: making disability count, https://alterconf2016. sciencesconf.org/data/pages/book_alterconf2016_3sept.pdf.

Goffman E. (2007), Piętno. Rozważania i zranionej tożsamości, GWP, Gdańsk.

Groce N. (2016), Begging among Persons with Disabilities in Addis Ababa, Ethiopia, https://alterconf2016.sciencesconf.org/data/pages/book_alterconf2016_3sept.pdf.

Grue J. (2016), Now You See It, Now You Don't: Disability Studies in a Disciplinary World, https://alterconf2016.sciencesconf.org/data/pages/book_alterconf2016_3sept.pdf.

Gruson C. (2017), Quand Gender et Disability studies ne se rencontrent pas?, https://alterconf 2017.sciencesconf.org/data/pages/Book_alterconf2017_fr.pdf.

Guevel M.R. (2016), Barriers and facilitators to access paid jobs, https://alterconf2016.sciencesconf.org/data/pages/book_alterconf2016_3sept.pdf.

Gustavsson A. (2016), Complexity and Continuity-identity constructions of persons with intellectual disabilities, https://alterconf2016.sciencesconf.org/data/pages/book_alterconf2016_3sept.pdf.

Gustafsson J. (2018), Supported employment and social inclusion at the workplace, wystapienie wygłoszone podczas Conférence ALTER 2018 Transformer les pratiques et les connaissances au prisme du handicap : expériences, transmissions, formations, organisations, Uniwersytet Katolicki, Lille.

Halvorsen (2017), Connecting lived lives and disability policy change in Europe-outline of a theoretical strategy, https://alterconf2017.sciencesconf.org/data/pages/Book_alterconf2017_ fr.pdf.

Hatsbacka (2017), The experiences of societal participation of people with disabilities: An interviewstudy among people with disabilities in Finland, https://alterconf2017.sciencesconf.org/ data/pages/Book_alterconf2017_fr.pdf.

Kittelsaa A. (2016), Changes in services - changes in attitudes, https://alterconf2016.sciencesconf.org/data/pages/book_alterconf2016_3sept.pdf

Kitchen, (2017), Theorizing Social Understandings and Representations of Deafness and Deaf People through Cinema, https://alterconf2017.sciencesconf.org/data/pages/Book_alterconf2017_ fr.pdf.

Krzemińska D., Lindyberg I. (2016), Individual concepts and experiences of adulthood of people with intellectual disabilities in the context of inclusion/exclusion, participation and human rights, https://alterconf2016.sciencesconf.org/data/pages/book_alterconf2016_3sept.pdf.

Lane C. (2016), A minority within a minority: Being transgender and having an intellectual disability, https://alterconf2016.sciencesconf.org/data/pages/book_alterconf2016_3sept.pdf. 
Larsson S. (2016), People with support from the Swedish Disability Act - included or in charge?, https://alterconf2016.sciencesconf.org/data/pages/book_alterconf2016_3sept.pdf.

Leonor M., Cláudia L. (2017), Voices of young adults with disability, https://alterconf2017. sciencesconf.org/data/pages/Book_alterconf2017_fr.pdf.

Lindqvist R. (2015), Active citizenship for persons with psychosocial disabilities in Sweden: a lifecourse perspective, https://alterconf2015.sciencesconf.org/conference/alterconf2015/pages/Livret.pdf.

Lindqvist E., Lagercrantz M. (2016), Monitoring UNCRPD in a national perspective, https://alterconf2016.sciencesconf.org/data/pages/book_alterconf2016_3sept.pdf.

Lindqvist R. (2017), Disability policies in Japan and Sweden, https://alterconf2017.sciencesconf.org/data/pages/Book_alterconf2017_fr.pdf.

Lynch P. (2016), Perspectives on difference and stigma: researching the lives of people with albinism in Malawi, https://alterconf2016.sciencesconf.org/data/pages/book_alterconf2016_ 3sept.pdf.

Magnanini A. (2017), Sexuality: a risk or a right? Conceptualisations of sexual expression by personnel in disability services, https://alterconf2017.sciencesconf.org/data/pages/Book_alterconf2017_fr.pdf.

McRuer R. (2016), Crip [w:] Keywords for Radicals: The Contested Vocabulary of Late-Capitalist Struggle, red. Kelly Frisch et al. Polskie wydanie: Interia, pismo poświęcone studiom queer, 11b, tłum. D. Ferens.

Mithout A.L. (2017), Aoi Shiba no Kai's strategy in Japanese society: uncompromising self-assertion at the risk of isolation, https://alterconf2017.sciencesconf.org/data/pages/Book_alterconf2017_fr.pdf.

Mladenov T. (2015), Questioning productivism through the lens of disability: reflections on state socialist and postsocialist disability policy, https://alterconf2015.sciencesconf.org/conference/alterconf2015/pages/Livret.pdf.

Nogueira J. (2015), The myths and the facts of disability and work in Portugal, https://alterconf2015.sciencesconf.org/conference/alterconf2015/pages/Livret.pdf.

Norberg I. (2015), Representations of disability in Swedish political debates, https://alterconf2015.sciencesconf.org/conference/alterconf2015/pages/Livret.pdf.

Ondrusova D. (2016), Overview of the policies implemented, https://alterconf2016.sciencesconf.org/data/pages/book_alterconf2016_3sept.pdf.

Pfahl L. (2017), Claiming Equality, Human and Social Rights in Europe: Formational Interventions of the Disability Movement in Austria, Germany and Switzerland in the 20th Century, https://alterconf2017.sciencesconf.org/data/pages/Book_alterconf2017_fr.pdf.

Pinto P. (2016), Out of the shadows: Uncovering violence against women and girls with disabilities in Portugal, https://alterconf2016.sciencesconf.org/data/pages/book_alterconf2016_3sept.pdf.

Schreue N. (2018), How do employees with ASD and their employers perceive workplace accessibility?, wystąpienie wygłoszone podczas Conférence ALTER 2018 - Transformer les pratiques et les connaissances au prisme du handicap : expériences, transmissions, formations, organisations, Uniwersytet Katolicki, Lille.

Schuller, Bickenbach, Trezzini (2017), Being disabled in Switzerland: coping strategies of persons with impairments facing barriers to their participation in society, https://alterconf2017.sciencesconf.org/data/pages/Book_alterconf2017_fr.pdf. 
Sepulchre M. (2016), Citizenship in action: Swedish disabled people claim „Full Participation. Now!", https://alterconf2016.sciencesconf.org/data/pages/book_alterconf2016_3sept.pdf.

Snyder S.L., Mitchell D.T. (2006), Cultural Locations of Disability, University of Chicago Press, Chicago.

Shakespeare T. (1994), Cultural Representation of Disabled People: Dustbins for Disavowal? , Disability \& Society", vol. 9.3.

Sztompka P. (2005), Socjologia, Znak, Warszawa.

Tossebro J. (2017), Employer federation's initiative to promote employment among disabled people, https://alterconf2017.sciencesconf.org/data/pages/Book_alterconf2017_fr.pdf.

Takahashi R. (2017), Universal and special conditions for advocating disability rights: from the experiences of Japan and Korea, https://alterconf2017.sciencesconf.org/data/pages/Book_alterconf2017_fr.pdf.

Tossebro J. (2016), Growing up with disability in Norway- family perspectives, https://alterconf2016.sciencesconf.org/data/pages/book_alterconf2016_3sept.pdf.

Tossebro J. (2015), Scandinavian Disability Policy - from deinstitutionalization to anti-discrimination?, https://alterconf2015.sciencesconf.org/conference/alterconf2015/pages/Livret.pdf.

The Making of Disability in Contemporary Russia (2018), Sesja tematyczna $7^{\text {th }}$ annual Conférence of ALTER 2018 - Transformer les pratiques et les connaissances au prisme du handicap: expériences, transmissions, formations, organisations, Uniwersytet Katolicki, Lille.

Uhasselt (2017), Disabled employees: identity work within organizational disability regimes: a study of 3 Belgian cases, https://alterconf2017.sciencesconf.org/data/pages/Book_alterconf2017_ fr.pdf

Vedeler, Olsen (2016), Hate speech targeted at disabled persons, https://alterconf2016.sciencesconf.org/data/pages/book_alterconf2016_3sept.pdf.

Waldschmit A. (2017), Disability Goes Cultural [w:] Culture-Disability - Theory, A. Waldschmit, H. Berressem, M. Ingwersem (red.), Bielefeld.

Waldschmidt A. (2016), Towards cross-national convergence of disability politics? A comparative study on the involvement of disability organisations in UN CRPD implementation processes in European countries, https://alterconf2016.sciencesconf.org/data/pages/book_alterconf2016_ 3sept.pdf.

Waldschmit A. (20170, Changing Disability Policies in the Age of the UN CRPD: the Case of Germany, https://alterconf2017.sciencesconf.org/data/pages/Book_alterconf2017_fr.pdf.

Waldschmit A. (2017), Citizenship of / for Persons with Disabilities - Re?ections on an Ambivalent Concept, https://alterconf2017.sciencesconf.org/data/pages/Book_alterconf2017_fr.pdf.

Wälivaara, (2017), "I am one with the Force and the Force is with me": Depictions of Disability and Sexuality in Rouge One, https://alterconf2017.sciencesconf.org/data/pages/Book_alterconf2017_fr.pdf.

Wenckebach J. (2017), Evaluating the German Federal Law of Equal Treatment of Disabled Persons methods and results, https://alterconf2017.sciencesconf.org/data/pages/Book_alterconf2017_ fr.pdf.

Wegscheider A., Breinlinger S. (2016), Different Developments in Supported Employment policies, https://alterconf2016.sciencesconf.org/data/pages/book_alterconf2016_3sept.pdf. 
Woynarowska A., Lindyberg I. (2015), Supporting vocational activity of people with intellectual disability in Poland, https://alterconf2015.sciencesconf.org/conference/alterconf2015/pages/Livret.pdf.

Woynarowska A., Rzeźnicka-Krupa J. (2016), Social activism of persons with disabilities in Poland - development and the current state of new social movements, https://alterconf2016.sciencesconf.org/data/pages/book_alterconf2016_3sept.pdf.

Woynarowska A. (2018), The employment policy and vocational activity support system for people with intellectual disabilities in Poland: life politics, emancipation or apparent actions?, wystąpienie wygłoszone podczas Conférence ALTER 2018 - Transformer les pratiques et les connaissances au prisme du handicap : expériences, transmissions, formations, organisations, Uniwersytet Katolicki, Lille. 